\title{
Mechanisms for Improving the Marketing of Agricultural Products for Increased Profitability
}

\author{
Cajethan U. Ugwuoke ${ }^{1} \quad$ Patience Ngozi Odoh ${ }^{1} \quad$ Godwin E. Eze $^{1} \quad$ Benedicta A. Omeje $^{1}$ \\ Nnennaya S. Monwuba ${ }^{2} \quad$ Scholastica U. Ekwueme ${ }^{1}$ \\ 1.Department of Agricultural Education, University of Nigeria, Nsukka \\ 2.Department of Vocational Education, Nnamdi Azikiwe University, Awka
}

\begin{abstract}
The high increase in agricultural production has resulted in farmers witnessing some challenges especially in the marketing of their agricultural products. In line with this, the study was aimed at identifying the mechanisms for improving the marketing of agricultural products for increased profitability. The study was guided by two research questions and two null hypotheses. The descriptive survey research design was adopted. The study which was carried out in Nsukka Local Government Area of Enugu State, Nigeria made use of 130 out of 350 registered farmers that reside in the rural and urban areas. The structured questionnaire used for data collection was validated by three experts from the Department of Agricultural Education, University of Nigeria, Nsukka and with a reliability coefficient of 0.65 established using Cronbach alpha method. Data collected were analyzed using mean to answer the research questions while t-test statistic was used to test the null hypotheses at 0.05 level of significance. The study revealed that different marketing outlets and mechanism could be adopted to increase the marketing of Agricultural products and thus, making a high profit. It was therefore recommended that government should construct good road networks for easy transportation of the agricultural product to the markets.
\end{abstract}

Keywords: marketing, agricultural products, increased profitability, farmers

DOI: $10.7176 / \mathrm{JMCR} / 62-04$

Publication date: November $30^{\text {th }} 2019$

\section{Introduction}

Agricultural production supports the vital economic sector of many households in Nigeria. It remains fundamental to poverty reduction and economic growth in the $21^{\text {st }}$ century (World Bank, 2008). As an enterprise, agriculture which is mainly seen as the cultivation of crops and rearing of farm animals is mainly for-profit maximization. As so, it has contributed a lot to individual and household income. A lot of scholars have perceived agriculture in different ways, some see it as farming while others see it as mere cultivation of crops and rearing of animals. The significance of agriculture is numerous and varied such as serving individual and industrial need as well as contributing to the economic growth of many countries. Agriculture is a sector of Nigeria's economy, engaging over $70 \%$ of the labour force and contributing about $40 \%$ to the Gross Domestic Product (GDP) (FMARD, 2015). Agriculture generates revenue for the government at the local, state and federal levels. It provides food to the teaming population, feeds for animals, raw materials for various industries and the development of rural communities (Eugene, 2007). Having attained this satisfaction, the desire for more satisfaction keep emerging and as a result of this, the exchange of agricultural products for other products (trade by barter) came into play until the formalized system of transaction was introduced. Baba and Etuk (1991) were of the view that agriculture has entirely become an enterprise which primarily seeks for interest in the transaction of its marketable products.

The need for agricultural marketing arises with the production of excess products which were above consumption. This resulted in the concept of marketable surplus which is defined as the proportion of the total output that is available for sale after satisfying the need of the producer. Marketing starts before production and ends after consumption. According to Nwoye (1997), marketing is human activity directed at satisfying needs and wants through exchange process. This definition has some keywords as the operative words, such as needs, wants and exchange. Wants are the expression of human needs as they are shaped by a person, culture and individual development. And want must be backed with money for it to be meaningful to the marketer. Exchange is obtaining the desired object from someone offering in return something of value. Marketing encompasses a series of activities involved in moving the goods from the point of production to the point of consumption. According to Olayemi (1994) the study of agricultural marketing comprises all the operations, and the agencies conducting them, involved in the movement of farm produce, foods, raw materials and their derivatives, such as textiles, from the farms to the final consumers, and the effects of such operations on farmers, middlemen and consumers.

Agricultural marketing is the study of all the activities, agencies and policies involved in the procurement of farm inputs and the movement of agricultural products from the farms to the consumers. The agricultural marketing system is a link between the farm and the non-farm sectors (Acharya, 2016). It includes the 
organization of agricultural raw materials supply to processing industries, the assessment of demand for farm inputs and raw materials, and the policy relating to the marketing of farm products and inputs. Agricultural marketing system in developing countries including Nigeria can be understood to comprise of two major subsystems viz., product marketing and input (factor) marketing. The actors in the product marketing sub-system include farmers, village/primary traders, wholesalers, processors, importers, exporters, marketing cooperatives, regulated market committees and retailers. The input subsystem includes input manufacturers, distributors, related associations, importers, exporters and others who make available various farm production inputs to the farmers. A dynamic and growing agricultural sector requires fertilizers, pesticides, farm equipment, machinery, diesel, electricity, packing material and repair services which are produced and supplied by the industry and nonfarm enterprises. The expansion in the size of farm output stimulates forward linkages by providing surpluses of food and natural fibres which require transportation, storage, milling or processing, packaging and retailing to the consumers. These functions are obviously performed by non-farm enterprises. Furthermore, if the increase in agricultural production is accompanied by a rise in real incomes of farm families, the demand of these families for non-farm consumer goods goes up as the proportion of income spent on non-food consumables and durables tends to rise with the increase in real per capita income. Several industries, thus find new markets for their products in the farm sector. From the above definitions, marketing of agricultural produce can be looked at as the application of marketing knowledge to the marketing of agricultural produce. One may be correct to say that market starts when farmers plan their output in respect to expected market demand to pricing of the produce in relation to the existing market price till the product gets to the ultimate consumer. Another view of marketing in agriculture is the human activities directed at satisfying need and want through exchange of agricultural products. Uchendu (2013) viewed Agricultural marketing as comprising of all activities involved in supply of farm inputs to the farmers and movement of agricultural products from the farms to the consumers. Agricultural marketing system includes the assessment of demand for farm-inputs and their supply, post-harvest handling of farm products, performance of various activities required in transferring farm products from farm gate to processing industries and/or to ultimate consumers, assessment of demand for farm products and public policies and programme relating to the pricing, handling, and purchase and sale of farm inputs and agricultural products for profit-making.

Profit-making can be affected by the challenges encountered by farmers at the course of production and moving their goods from one particular point to another. Some farmers do not have storage facilities for their products, those who have lacked the method of preservation strategies. The need for these facilities is easily recognized in view of the enormous waste, profit loss and acute price instability of agricultural products. Some farmers do not know their customers and where to take their products due to poor marketing research. More so, lack of access to good road and transportation system has hindered agricultural products distribution. The idea of marketing mix is lacked by the farmers and the mix includes product, price, promotion and physical distribution. The interest of customers should be considered by the farmers before determining the kind of product to produce and introduce to the market for specific groups and according to the tastes and standards. In some developed countries this technique is applied by the government to decide what, when, and where, some social amenities are provided for the development programme. The uncertainty and price fluctuation faced by the farmers affect profit-making. If all this consideration is adequately addressed, farmers will be in a better position to make a good profit from the sales of their products.

Giron et al (2012) stated that viable marketing strategies or mechanism must be employed to drive the profitability of the products. The study is therefore aimed at determining the mechanisms for improving the marketing of agricultural products for increased profitability. Specifically, the study sought to determine the different mechanisms through which the marketing of agricultural products can be improved and the different marketing outlets that could be adopted to increase the marketing of agricultural products.

\section{Research Questions}

The study is guided by the following research questions:

1. What are the different mechanisms through which the marketing of agricultural products could be improved?

2. What are the different marketing outlets that could be adopted to increase the marketing of agricultural products?

\section{Research Hypotheses}

$\mathbf{H O}_{1}$ : There is no significant difference between the mean ratings of farmers located in urban and rural areas on the mechanisms through which the marketing of agricultural products could be improved?

$\mathbf{H O}_{2}$ : There is no significant difference between the mean ratings of farmers located in urban and rural areas on the marketing outlets that could be adopted to increase the marketing of agricultural products? 
Methodology

The study adopted a descriptive survey research design. The population for the study was 350 registered farmers in Nsukka local government area of Enugu State. Simple random sampling technique was used to select 130 farmers for the study. A structured questionnaire was developed to elicit responses from the respondents. The questionnaire was validated by three experts from the Department of Agricultural Education, University of Nigeria, Nsukka and a reliability coefficient of 0.67 was obtained through Cronbach alpha method. One hundred and thirty copies of the instrument were administered to the respondents and 120 retrieved giving a return rate of $92 \%$. Mean and the standard deviation was used to answer the research questions while t-test statistic was used to test the null hypothesis at 0.05 level of significance. A null hypothesis was accepted when the probability value was equal or greater than $0.05(\mathrm{p} \geq 0.05)$ and rejected when the probability value was less than 0.05 $(\mathrm{p}<0.05)$.

\section{Results}

Data collected from the study were analyzed based on the objectives and hypotheses formulated for the study.

Table 1: Description of Respondents' Demographic Characteristics

\begin{tabular}{clll}
\hline S/N & Characteristics & Frequency (f) & Percentage (\%) \\
\hline $\mathbf{1 .}$ & Sex & & \\
& Male & 85 & 70.8 \\
& Female & 35 & 29.2 \\
& Total & $\mathbf{1 2 0}$ & $\mathbf{1 0 0}$ \\
2. & Type of Farming & 26 & \\
& Crop production & 38 & 21.7 \\
& Livestock production & 56 & 31.6 \\
& Both of them & $\mathbf{1 2 0}$ & 46.7 \\
& Total & & $\mathbf{1 0 0}$ \\
3. & 18 & 15 \\
& Years of Farming Experience & 28 & 23.3 \\
& 6-5 years & 35 & 29.2 \\
& 11-15 years & 39 & 32.5 \\
& 16 years and above & $\mathbf{1 2 0}$ & $\mathbf{1 0 0}$ \\
\hline
\end{tabular}

The result in Table 1 showed that there was a higher number of male farmers in the study area than females. The table indicated that males were 85 from the sample size of 120 amounting to $70.8 \%$ in the overall while female respondents were $35(29.2 \%)$. The table also revealed that most of the farmers were both crop and livestock farmers. Among the respondents, farmers under crop production were $26(21.7 \%)$ while those in livestock were 38 (31.6\%). More so, those that practised both crop and animal production were $56(46.7 \%)$. It was equally observed that farmers who had experience of 16 years and above in farming had the highest number of $39(32.5 \%)$ which was followed by the farmers who had a farming experience of 11-15 years with the number of $35(29.2 \%)$. Similarly, farmers with working experience of 6-10 years were $28(23.3 \%)$ while farmers with working experience of 1-5 years had the least number of $18(15 \%)$.

Result in Table 2 showed that the items 1, 2, 7 and 10 had their means ranging from 3.50-3.86 which signifies that the respondents strongly agreed that processing of products before sale, grading the products, storage of the products and providing warehousing, and preserving the perishable produce to avoid spoilage are the mechanisms through which marketing of agricultural products could be improved. Similarly, items 3, 4, 5, 6, 9 and 11 had their means ranging from 3.00-3.45 which implies that the respondents agree that branding of the products, transportation, advertising in social media, packaging the products, handing the product over to commission agents and sorting the produce are the mechanisms through which marketing of agricultural products could be improved. However, item 8 had a mean value of 2.34 which shows that the respondents disagree that fixing prices of products before selling is the mechanism through which marketing of agricultural products could be improved. The standard deviation of the items ranged from 0.54 to 1.6. This shows that the respondents were close to one another in their responses and that they were not far from the mean.

The probability values of the entire items were greater than 0.05 (Table 2). This shows that there is no statistically significant difference $(p>0.05)$ in the mean responses of urban and rural farmers on the mechanisms through which the marketing of agricultural products could be improved. The null hypothesis is therefore accepted. 
Table 2: Mean and t-test Analysis of Different Mechanisms through which Marketing of Agricultural Products could be Improved $\quad \mathrm{N}=120$

\begin{tabular}{|c|c|c|c|c|c|c|c|c|c|c|}
\hline $\mathbf{S} / \mathbf{N}$ & Statement of items & X G & SD & Dec & $\bar{X}_{1}$ & SD1 & $\bar{X} 2$ & SD2 & $\begin{array}{l}\text { P- } \\
\text { Value }\end{array}$ & Rem \\
\hline 1 & Processing of the products before selling & 3.86 & 0.75 & SA & 3.87 & 0.75 & 3.85 & 0.51 & 0.97 & NS \\
\hline 2 & $\begin{array}{l}\text { Grading the products according to size } \\
\text { and quality }\end{array}$ & 3.50 & 0.76 & SA & 3.48 & 0.78 & 3.52 & 0.38 & 0.22 & NS \\
\hline 3 & Branding of the produce & 3.06 & 0.43 & A & 3.03 & 0.98 & 3.09 & 0.50 & 0.38 & NS \\
\hline 4 & $\begin{array}{l}\text { Transportation of the products near the } \\
\text { consumers }\end{array}$ & 3.21 & 1.6 & A & 3.40 & 1.05 & 3.02 & 0.50 & 0.82 & NS \\
\hline 5 & $\begin{array}{l}\text { Advertising the products in the social } \\
\text { media, television among others }\end{array}$ & 3.00 & 0.54 & A & 3.03 & 0.94 & 2.97 & 0.50 & 0.11 & NS \\
\hline 6 & Packaging of the products before selling it & 3.34 & 0.67 & A & 3.33 & 0.92 & 3.35 & 0.47 & 0.54 & NS \\
\hline 7 & $\begin{array}{l}\text { Storing the produce and providing } \\
\text { warehousing during the period of surplus }\end{array}$ & 3.54 & 0.65 & SA & 3.49 & 0.88 & 3.59 & 0.50 & 0.90 & NS \\
\hline 8 & Fixing of the price before selling them & 2.34 & 0.76 & $\mathrm{D}$ & 2.30 & 1.03 & 2.38 & 0.50 & 0.09 & NS \\
\hline 9 & $\begin{array}{l}\text { Handing the produce over to the } \\
\text { commission agents }\end{array}$ & 3.45 & 0.54 & A & 3.43 & 0.65 & 3.47 & 0.50 & 0.55 & NS \\
\hline 10 & $\begin{array}{l}\text { Preserving the perishable produce to avoid } \\
\text { spoilage }\end{array}$ & 3.54 & 0.56 & SA & 3.52 & 1.08 & 3.56 & 0.48 & 0.46 & NS \\
\hline 11 & $\begin{array}{l}\text { Sorting the produce to remove damaged } \\
\text { ones }\end{array}$ & 3.00 & 0.91 & A & 3.02 & 1.09 & 2.98 & 0.49 & 0.19 & NS \\
\hline
\end{tabular}

Table 3: Mean and t-test Analysis of the Different Marketing Outlets that could be Adopted to Increase the Marketing of Agricultural Products

$\mathrm{N}=120$

\begin{tabular}{|c|c|c|c|c|c|c|c|c|c|c|}
\hline $\mathbf{S} / \mathbf{N}$ & Statement of items & $\bar{X} \mathbf{G}$ & SD & Dec & $\mathrm{X}_{1}$ & SD1 & $\mathrm{X} 2$ & SD2 & $\begin{array}{l}\text { P- } \\
\text { Value }\end{array}$ & Rem \\
\hline 12 & $\begin{array}{l}\text { Selling the products in retail at the } \\
\text { Farmers' farms }\end{array}$ & 3.33 & 0.51 & A & 3.37 & 0.94 & 3.29 & 0.50 & 0.93 & NS \\
\hline 13 & Wholesale at the farmers' farms & 3.54 & 0.65 & SA & 3.52 & 0.78 & 3.56 & 0.47 & 0.85 & NS \\
\hline 14 & $\begin{array}{l}\text { Hawking the products along the } \\
\text { major high ways }\end{array}$ & 3.65 & 0.76 & SA & 3.61 & 0.73 & 3.69 & 0.50 & 0.71 & NS \\
\hline 15 & Creating road side shops & 3.30 & 0.43 & A & 3.43 & 0.59 & 3.37 & 0.67 & 0.59 & NS \\
\hline 16 & $\begin{array}{l}\text { Creating on-line marketing via website or } \\
\text { blog: social media marketing via Facebook, } \\
\text { instergram. whatSapp, etc }\end{array}$ & 3.54 & 0.67 & SA & 3.50 & 0.56 & 3.58 & 0.51 & 0.66 & NS \\
\hline 17 & Taking the produce to the local markets & 3.67 & 0.80 & SA & 3.63 & 0.76 & 3.71 & 0.49 & 0.13 & NS \\
\hline 18 & Personal contact with buyers & 3.00 & 0.75 & A & 3.02 & 0.63 & 2.98 & 0.49 & 0.35 & NS \\
\hline 19 & Exporting to other countries & 3.86 & 0.32 & SA & 3.84 & 0.56 & 3.88 & 0.51 & 0.30 & NS \\
\hline 20 & $\begin{array}{l}\text { Through exhibiting at trade fairs and public } \\
\text { meetings }\end{array}$ & 3.54 & 0.56 & SA & 3.57 & 0.50 & 3.51 & 0.45 & 0.07 & NS \\
\hline 21 & Use of hand bills and signpost, etc & 2.29 & 0.75 & D & 2.26 & 0.52 & 2.32 & 0.47 & 0.15 & NS \\
\hline
\end{tabular}

Key - X $G$ - Grand mean, SD - Standard deviation, Dec - Decision, SA-Strongly agreed, A-agree, $\overline{\mathrm{X}}-\mathrm{Mean}$, Rem-Remark, NS - Not significant, D - Disagree

The data presented in the Table 3 shows that items 13,14,16, 17, 19 and 20 had the mean values ranging from 3.54-3.86 which implies that the respondents strongly agree that wholesale in the farmers' farms, hawking the products, creating online marketing, selling in the local markets, exporting to other countries and exhibition at trade fairs are the different marketing outlets that could be adopted to increase the marketing of agricultural products. Similarly, items 12, 15 and 18 had their mean values ranged from 3.30-3.33 which shows that the respondents agree that selling in retails in the farmer's farms, creating roadside shops, and personal contact with the buyers are the different marketing outlets that could be adopted to increase the marketing of agricultural products. However, item 21 had the mean value of 2.29 which shows that the respondents disagree that use of handbills and signposts are the marketing outlets that could be adopted to increase the marketing of agricultural products. The standard deviation of the items ranged from 0.32 to 0.80 . This indicated that the respondents were close to one another in their responses as they were not far from the mean. 
Furthermore, data in Table 3 shows that the entire p-values are greater than 0.05 . This signifies that there is no significant difference $(\mathrm{P}>0.05)$ in the mean responses of the respondents on the different marketing outlets that could be adopted to increase the marketing of agricultural products. The hypothesis of no significant difference is therefore upheld.

\section{Discussion of the Findings}

The study found out that processing of agricultural products before sale, grading, branding of the produce, transportation near the consumers, advertising the products, packaging, storage or warehousing, preservation to avoid spoilage and sorting are the different mechanisms through which marketing of agricultural products could be improved. The findings were in line with Asogwa and Okwoche (2012) who reported that agricultural products are likely located some distance away from the place of consumption and therefore need to be transported. Storage is equally required to adjust supply to meet demand. The authors reiterated that harvested products are rarely in a form acceptable to consumers and must be sorted, cleaned, processed in various forms and presented to consumers in convenient quality to increase the economic value. In his study, Gbam (2017) discovered that transportation plays a significant role in creating market for agricultural products by conveying farm products to where they are needed. The author maintained that good transportation system helps in reducing spoilage and wastages of farm products and increase profitability. Farmers need to adopt farm level grading and processing to track their profit in a competitive agricultural market (Ogbonna, 2017). The author emphasized the farmers who improve the value of their agricultural produce stand a better chance of making profit from their proceeds.

The study further found out that selling the products in retails in the farmers' farm, wholesale at the farmers' farm, hawking the products, creating roadside shops, creating online and social media marketing, selling at the local markets, selling through the personal contact with the buyers, exporting to other countries and exhibiting at trade fairs and public meetings are the different marketing outlets that can be adopted to increase the marketing of agricultural products. The findings are in agreement with Mwagha and Ntongeendu (2014) who reported that customers could order agricultural products online, make payments using PayPal, and receive feedback through email. In line with the findings, Asogwa and Okwoche (2012) discovered that sorghum is sold through different outlets as marketing agents accounts for $70 \%$ sales, retailers $8 \%$, wholesalers $20 \%$ and farmers $2 \%$. The authors went further to report that $65 \%$ sale of sorghum is done in the market square, $20 \%$ at the roadside, $10 \%$ at the farm while $5 \%$ are sold through hawking.

\section{Conclusions}

Based on the data collected and analyzed, it was concluded that processing of agricultural products before sale, grading, branding of the produce, transportation near the consumers, advertising the products, packaging, storage or warehousing, preservation to avoid spoilage and sorting are the different mechanisms through which marketing of agricultural products could be improved. Selling the products in retails in the farmers' farm, wholesale at the farmers' farm, hawking the products, creating roadside shops, creating online and social media marketing, selling at the local markets, selling through the personal contact with the buyers, exporting to other countries and exhibiting at trade fairs and public meetings are the different marketing outlets farmers can be adopted to increase the marketing of agricultural products.

\section{Recommendations}

Based on the findings of the study, the following were recommended:

1. The government should construct good network of roads for easy transportation of agricultural products to the markets and urban areas.

2. Farmers should adopt good marketing strategies where the agricultural product will be processed, packaged and distributed for better economic value.

3. Farmers should diversify their sales outlets instead of selling at the farm gates.

\section{References}

Acharya S.S and Agrawal N.L. (2016.) Agricultural marketing in India. New Delhi, Oxford \& IBH Publishing Co Pvt Ltd.

Asogwa, B.C. and Okwoche, V.A. (2012). Marketing of Agricultural Produce among Rural Farm Households in Nigeria: The Case of Sorghum Marketing in Benue State. International Journal of Business and Social Science, 3(13), 269-277

Baba, K.M and Etuk E.G. (1991). Resource use efficiency and constraints in irrigated agriculture: empirical evidence from Bauchi State, Nigeria. Nigerian Journal of Agricultural Technology 3, 10-21

Gbam, B. and Naiker, K.L. (2017). Effect of Transportation on the Marketing of Agricultural Products in Jos North. Journal of Research in Business and Management, 5(2), 99-106 
Eugene, H. (2007). Farm and Infrastructure Foundation. New Agricultural Digest, 1(6): 5-7.

Federal Ministry of Agriculture and Rural Development (FMARD) (2015). National Agricultural Resilience Framework. A Report by the Advisory Committee on Agricultural Resilience in Nigeria. Retrieved from https://fmard.gov.ng/wp-content/uploads/2018/04/NARF-Main-document.pdf

Giron, D., Frago, E., Glevarec, G., Pieterse, C.M.J. and Dicke, M. (2013). Cytokinins as key regulators in plants-microbes-insects interactions: connecting plant growth and defence. Functional Ecology, 27, $599-609$

Mwagha, S.M. and Ntonge"ondu, H.K. (2014). An agricultural product e-business system: a case of Khat ebusiness in Kenya. International Journal of Business, Economics and Management Works, 1(2), 30-34

Nwoye, M.U. (1997). The economics of rice production by small-holder farmers in Anambra State. Unpublished Master's Degree Thesis, University of Nigeria, Nsukka.

Ogbonna S.E. (2017) New focus in Animal husbandry for schools and colleges. Onitsha, Kenbest Printing and publication Co.

Olayemi, J.K. 1994. Agricultural policies for sustainable development: Nigeria experience. In Sustainable agriculture and economic development in Nigeria, Washington DC, A. Ikpi and J.K Olayemi Winrock International

Uchendu, E.C. (2013). Rurality as a choice: Towards ruralising rural areas in sub-Saharan African countries. Development Southern Africa, 30(6) 812-825

World Bank (2008). The World Bank Annual Report 2008 Year in Review. Retrieved from http://siteresources.worldbank.org/EXTANNREP2K8/Resources/YR00_Year_in_Review_English.pdf 